\title{
Anti-Staphylococcus aureus activity of methanol extracts of 12 plants used in Cameroonian folk medicine
}

\author{
Leonard Sama Fonkeng ${ }^{1}$, Raymond Simplice Mouokeu², Christopher Tume ${ }^{1 *}$, Guy Sedar Singor Njateng ${ }^{1}$, \\ Monique Odette Kamcthueng ${ }^{1}$, Nfozon Jinette Ndonkou ${ }^{1}$ and Jules-Roger Kuiate ${ }^{1}$
}

\begin{abstract}
Background: The emergence of bacterial infections including those associated with Staphylococcus aureus causes a benefit of interest to medicinal plants as an effective means of control. The present study was designed to investigate the activities of 12 selected Cameroonian medicinal plants against $S$. aureus isolates.

Methods: The plant extracts were prepared by maceration in methanol at laboratory temperature. Qualitative phytochemical analysis was performed by chemical reaction methods. The broth microdilution method was used to evaluate the activities of plant extracts against $11 \mathrm{~S}$. aureus clinical isolates.

Results: Dacryodes edulis was found to have significant antibacterial activity on all the $S$. aureus isolates $(\mathrm{MIC}=64-256 \mu \mathrm{g} / \mathrm{ml})$. Occimum gratissimum revealed significant inhibitory activity on 9 of the 11 isolates while Commelina erecta and Spilanthes filicaulis revealed similar results on 6 of the 11 clinical isolates.
\end{abstract}

Conclusion: The present findings showed that D. eduli, O. gratissimum, C. erecta and S. filicaulis possess interesting inhibitory properties against $S$. aureus species. These plants could therefore be good candidates to overcome infectious diseases associated with these microorganisms.

Keywords: Medicinal plant, Staphylococcus aureus, Antibacterial activity, Cameroonian folk medicine

\section{Background}

Infectious diseases are becoming a major cause of human and animal mortality and morbidity. This is further aggravated by the rapid development of multi-drug resistance, limited antibacterial spectrum and adverse effects of available antimicrobial agents [1]. Human pathogenic bacteria include amongst others Staphylococcus aureus; a major cause of bacteremia, associated with higher morbidity and mortality compared to other bacteremia-causing pathogens [2]. The burden of S. aureus bacteremia, particularly methicillin-resistant $S$. aureus bacteremia is due to the fact that, it is highly expensive in terms of cost and resource. The incidence of $S$. aureus bacteremia

\footnotetext{
*Correspondence: tumechrist@yahoo.com

1 Laboratory of Microbiology and Antimicrobial Substances, Faculty

of Science, P.O. Box 67, Dschang, Cameroon

Full list of author information is available at the end of the article
}

and its complications has increased abruptly in recent years because of the increased frequency of invasive procedures which has led to great number of immunocompromised patients and resistance of $S$. aureus strains to available antibiotics. This changing epidemiology of $S$. aureus bacteremia, in combination with the inherent virulence of the pathogen, is commanding an urgent need for improved strategies and better antibiotics to prevent and treat S. aureus bacteremia [3, 4].

The investigation of certain indigenous plants for their antimicrobial properties may yield useful results. This has consequently increased the attention and demand given to antimicrobials derived from the plants [5]. Natural products, either as pure compounds or as standardized plant extracts, provide exceptional opportunities for new drug leads because of the unmatched chemical diversity of naturally derived compounds [6, 7]. The medicinal value of plants is associated with some 
chemical substances also known as phytochemicals that produce a definite physiological action on humans. The present study was designed to investigate the activities of 12 selected Cameroonian medicinal plants against $S$. aureus clinical isolates.

\section{Methods}

\section{Collection and identification of plant samples}

Twelve plant samples were used in this study. They were collected either from Santchou or Dschang in April 2011, Menoua division, West Region of Cameroon. The taxonomical authentication of identity was undertaken by a botanist at the National Herbarium of Cameroon in Yaounde where voucher specimens were deposited. For each plant, the part used, the identification code, previous studies and ethnobotanical surveys are presented in Table 1.

Preparation of plant extracts and preliminary qualitative phytochemical screening

The leaves or the stems of each plant were air-dried at room temperature $\left(20 \pm 4{ }^{\circ} \mathrm{C}\right)$ before grinding to powder with a mechanical grinder. The powder (150 g) was macerated in methanol $(300 \mathrm{ml})$ for 4 days with a three times daily shaking, the mixture was then filtered using Whatmann filter paper No. 1. The filtrate was concentrated at $50{ }^{\circ} \mathrm{C}$ under reduced pressure using a rotary evaporator (Buchi R-200) and further dried using a vacuum concentrator (SC250EXP).

The qualitative phytochemical analysis was performed following standard methods [21].

\section{Microorganisms}

A total of 11 clinical isolates of $S$. aureus were used. They were isolated locally on Mannitol salt agar slant (Conda, Madrid, Espagne) from patients with urogenital infections. The species was confirmed following morphological observations and biochemical tests [22]. These micro-organisms were maintained in agar slants.

\section{Antimicrobial susceptibility testing}

Luria-Bertani agar (Himedia, India) was used for the upkeeping of the isolates, whereas Luria-Bertani broth (LBB) was used for antimicrobial susceptibility testing using broth microdilution method.

The antibacterial activity was investigated by determining the minimum inhibitory concentrations (MICs) and the minimum bactericidal concentrations (MBCs). The

Table 1 Information on the plants used, yields of extraction and report on evidence of their activities

\begin{tabular}{|c|c|c|c|c|c|c|}
\hline Plant name & $\begin{array}{l}\text { Parts use } \\
\text { tradionally }\end{array}$ & $\begin{array}{l}\text { Locality } \\
\text { of harvest }\end{array}$ & Yields (\%) & $\begin{array}{l}\text { Ethnobotanical } \\
\text { relevance }\end{array}$ & $\begin{array}{l}\text { Identification } \\
\text { code }\end{array}$ & Previous scientific studies \\
\hline $\begin{array}{l}\text { Acalypha frutucosa } \\
\text { Forssk }\end{array}$ & Leaf & Santchou & 3.43 & $\begin{array}{l}\text { Skin infections and } \\
\text { diarrhoea }\end{array}$ & $33,034 / \mathrm{HNC}$ & $\begin{array}{l}\text { Antimicrobial and antioxidant } \\
\text { activity [8] }\end{array}$ \\
\hline $\begin{array}{l}\text { Aspilia africana CD/ } \\
\text { Adams }\end{array}$ & Leaf & Santchou & 2.51 & Wound treament & 16,935/SRF Cam & Antiulcer activity [9] \\
\hline Commelina Erecta & Leaf & Santchou & 1.56 & $\begin{array}{l}\text { Eczema and skin infection } \\
\text { treatment }\end{array}$ & 22,595/SRF Cam & / \\
\hline $\begin{array}{l}\text { Dacryodes edulis (Don) } \\
\text { H.J Lam }\end{array}$ & Leaf & Santchou & 4.44 & Stomach ache & 17,234/SRF Cam & $\begin{array}{l}\text { Phytochemical studies and } \\
\text { antimicrobial activity [10] }\end{array}$ \\
\hline Drymaria cordata Willd & & Dschang & 1.02 & Headache & 20,550/SRF Cam & Cytotoxic activity [11] \\
\hline $\begin{array}{l}\text { Eremomastax speciosa } \\
\text { Cufod }\end{array}$ & Leaf & Dschang & 2.26 & Nappy rash treatment & $36,228 / H N C$ & $\begin{array}{l}\text { Antidiarrhoea and } \\
\text { antimicrobial activity }[12,13]\end{array}$ \\
\hline Kalanchoe crenata Andr & ArLeaf & Santchou & 10.92 & $\begin{array}{l}\text { Ear infection, rheumatism } \\
\text { and inflammatory } \\
\text { treatment }\end{array}$ & 50,103/YA Cam & $\begin{array}{l}\text { anti-inflamatory and } \\
\text { antibacterial activity }[14,15]\end{array}$ \\
\hline $\begin{array}{l}\text { Occimum gratissimum } \\
\text { linn Hochst }\end{array}$ & Leaf & Santchou & 9.54 & Food plant & $42,850 / \mathrm{HNC}$ & $\begin{array}{c}\text { Antimicrobial and } \\
\text { phytochemical } \\
\text { studies }[16,17]\end{array}$ \\
\hline Portulaca oleracea & Leaf & Dschang & 4.61 & Food plant & $17,542 / S R F$ Cam & $\begin{array}{l}\text { Antimicrobial and } \\
\text { phytochemical } \\
\text { studies [18] }\end{array}$ \\
\hline Scoporia dulcis Linn & Leaf & Santchou & 8.12 & Stomach ache & 22,595/SRF Cam & Antidiabetic activity [19] \\
\hline Sida veronicifolia Linn & Leaf and steam & Santchou & 1.11 & Stomach ache & 20,859/SRF Cam & Antioxydant activity [20] \\
\hline $\begin{array}{l}\text { Spilanthes filicaulis } \\
\text { C.D. Adams }\end{array}$ & Leaf and steam & Santchou & 5.54 & $\begin{array}{l}\text { Headache, fontanel, } \\
\text { teeth pain, angina }\end{array}$ & 20,447/SFR Cam & $\begin{array}{l}\text { Phytochemical studies and } \\
\text { antiulcer activity [9] }\end{array}$ \\
\hline
\end{tabular}


MICs value of the plant extracts were determined using a rapid p-Iodonitrotetrazolium (INT) chloride (SigmaAldrich, France) colorimetric assay [23]. Briefly, stock solutions of plant extracts were prepared in $5 \%(\mathrm{v} / \mathrm{v})$ dimethylsulfoxide (DMSO) solution (Fisher chemicals, France). The solution obtained was then diluted with LBB (Himedia, India) to give a final concentration of $4096 \mu \mathrm{g} /$ ml. $100 \mathrm{ml}$ of each extract solution was introduced into the first three wells of 96-wells microtitre plate containing $100 \mu \mathrm{l}$ of LBB and further twofold serially diluted to obtain concentrations ranging from 1024 to $8 \mu \mathrm{g} / \mathrm{ml}$. $100 \mathrm{ml}$ of bacterial suspensions of about $1.5 \times 10^{8} \mathrm{CFU} /$ $\mathrm{ml}$ following Mc Farland turbidity standard no. 0.5, 100 times diluted, were introduced into each well containing $100 \mu \mathrm{l}$ mixture of LBB and extract. The final concentration of DMSO was less than $1 \%$. Wells containing LBB, inoculum and DMSO at a final concentration of $1 \%$ served as the negative control. Ciprofloxacin (SigmaAldrich, France) was used as reference antibiotic. The plates were covered with a sterile plate sealer and then agitated with a shaker. They were further incubated at $35{ }^{\circ} \mathrm{C}$ for $24 \mathrm{~h}$. Upon incubation, $40 \mu \mathrm{l}$ of $2 \%$ INT solution were added in each well. Viable bacteria reduced the yellow dye of INT to pink. All the concentrations that did not show color change were considered, and the smallest was noted as MIC value of each extract on the isolate.

For the well that did not received INT, $50 \mu \mathrm{l}$ of solution of the corresponding well that did not present color change was withdrawn out and seeded into the wells of new plates containing $150 \mu \mathrm{l}$ of newly LBB prepared. The mixture was further incubated at $35^{\circ} \mathrm{C}$ for $48 \mathrm{~h}$. After the incubation period, $40 \mu \mathrm{l}$ of INT solution were introduced in each well. The MBCs were considered as the lowest concentration of the extract that prevents INT color change [23].

\section{Results}

Qualitative phytochemical composition

Freshly prepared extracts were subjected to phytochemical screening for various constituents. The results revealed the presence of Phytochemical compounds including alkaloids, anthocyanins, anthraquinones, flavonoids, phenols, tannins and triterpenes (Table 2). Only Dacryodes edulis extract was found to contain saponins.

\section{Antibacterial activity}

The antibacterial activities of the 12 plant extracts on $S$. aureus isolates are presented in Table 3. D. edulis and Occimum gratissimum with MIC values ranging from 64-256 $\mu \mathrm{g} / \mathrm{ml}$ were found to have the best inhibitory activity on almost all the tested microorganisms. Scoparia dulcis, Spilanthes filicaulis, Commelina erecta and E. spciosa with MIC $=64-512 \mu \mathrm{g} / \mathrm{ml}$ were found to have similar antibacterial activity, being more active compared to Kalanchoe crenata (MIC $=512-1024 \mu \mathrm{g} /$ $\mathrm{ml})$. Aspilia africa, Drymaria cordata, Portulaca oleracea and Sida veronicifolia were almost inactive on these microorganisms.

Considering all the inhibitory activity, MICs values of all the active plant extracts were almost fourfold less than their MBCs values.

\section{Discussion}

The plants selected in this study are all used in Cameroonian traditional medicine to overcome a wide range of diseases. Ethno-pharmacological data have confirmed their role in health maintenance and promotion, but the major challenge is either to provide scientific evidence or to produce complementary data of their previous well established antibacterial properties.

Table 2 Qualitative phytochemical composition of the plant extracts

\begin{tabular}{|c|c|c|c|c|c|c|c|c|c|c|c|c|}
\hline & $\begin{array}{l}\text { A. afri- } \\
\text { cana }\end{array}$ & $\begin{array}{l}\text { A. frutu- } \\
\text { cosa }\end{array}$ & C. erecta & $\begin{array}{l}\text { D. cor- } \\
\text { data }\end{array}$ & D. edulis & $\begin{array}{l}\text { E. spe- } \\
\text { ciosa }\end{array}$ & $\begin{array}{l}\text { K. cre- } \\
\text { nata }\end{array}$ & $\begin{array}{l}\text { O. gratis- } \\
\text { simun }\end{array}$ & $\begin{array}{l}\text { P. olera- } \\
\text { cea }\end{array}$ & S. dulcis & $\begin{array}{l}\text { S. filicau- } \\
\text { lis }\end{array}$ & $\begin{array}{l}\text { S. veronici- } \\
\text { folia }\end{array}$ \\
\hline Phenols & + & + & + & + & + & + & + & + & - & + & - & + \\
\hline Saponins & - & - & - & - & + & - & - & - & - & - & - & - \\
\hline Tannins & - & + & - & + & + & - & + & - & - & - & - & - \\
\hline Flavonoids & - & - & + & + & + & + & + & + & - & + & + & + \\
\hline $\begin{array}{l}\text { Anthraqui- } \\
\text { nones }\end{array}$ & - & + & - & - & + & - & - & - & + & - & - & - \\
\hline $\begin{array}{l}\text { Anthocya- } \\
\text { nins }\end{array}$ & - & - & - & + & + & + & - & + & + & + & + & + \\
\hline Alcaloids & + & - & + & - & + & - & - & - & + & + & - & - \\
\hline Sterols & + & - & + & - & + & - & + & + & + & + & - & + \\
\hline $\begin{array}{l}\text { Triterpe- } \\
\text { nes } \\
\text { + present; - }\end{array}$ & $\begin{array}{c}+ \\
\text { absent }\end{array}$ & - & + & + & - & + & + & - & + & + & - & + \\
\hline
\end{tabular}


Table 3 Minimal inhibitory concentrations and minimal bactericidal concentrations ( $\mu \mathrm{g} / \mathrm{ml}$ ) of plant extracts against Staphylococcus aureus isolates

\begin{tabular}{|c|c|c|c|c|c|c|c|c|c|c|c|}
\hline & $\begin{array}{l}\text { Staph } 23 \\
\text { JN }\end{array}$ & $\begin{array}{l}\text { Staph } \\
55 \mathrm{M}\end{array}$ & $\begin{array}{l}\text { Staph } 67 \\
\text { JN }\end{array}$ & $\begin{array}{l}\text { Staph } 18 \\
\text { JL }\end{array}$ & $\begin{array}{l}\text { Staph } \\
79 M\end{array}$ & $\begin{array}{l}\text { Staph } \\
58 \mathrm{M}\end{array}$ & $\begin{array}{l}\text { Staph } 22 \\
\text { JN }\end{array}$ & $\begin{array}{l}\text { Staph } \\
70 \mathrm{M}\end{array}$ & $\begin{array}{l}\text { Staph } 02 \\
\text { JN }\end{array}$ & $\begin{array}{l}\text { Staph } \\
94 \mathrm{M}\end{array}$ & $\begin{array}{l}\text { Staph } \\
75 \mathrm{~N}\end{array}$ \\
\hline \multicolumn{12}{|l|}{ A. africa } \\
\hline CMI & $>1024$ & $>1024$ & $>1024$ & $>1024$ & $>1024$ & $>1024$ & $>1024$ & $>1024$ & $>1024$ & $>1024$ & $>1024$ \\
\hline CMB & / & / & I & / & I & I & / & I & / & / & / \\
\hline $\mathrm{CMB} / \mathrm{C} \mathrm{Ml}$ & / & / & / & / & / & / & / & / & / & / & / \\
\hline \multicolumn{12}{|l|}{ A. frutucosa } \\
\hline $\mathrm{CMI}$ & $>1024$ & 512 & $>1024$ & $>1024$ & $>1024$ & $>1024$ & $>1024$ & $>1024$ & $>1024$ & 512 & $>1024$ \\
\hline $\mathrm{CMB}$ & / & 1024 & I & / & / & I & / & I & I & 1024 & I \\
\hline CMB/CMI & / & 2 & / & / & / & I & / & / & / & 2 & / \\
\hline \multicolumn{12}{|l|}{ C. erecta } \\
\hline $\mathrm{CMI}$ & $>1024$ & 128 & 256 & 128 & 256 & 256 & 512 & 512 & 512 & 256 & 512 \\
\hline$C M B$ & / & 1024 & 512 & 512 & $>1024$ & 512 & $>1024$ & $>1024$ & 1024 & 512 & $>1024$ \\
\hline $\mathrm{CMB} / \mathrm{CMI}$ & / & 8 & 2 & 4 & I & 2 & / & / & 2 & 2 & / \\
\hline \multicolumn{12}{|l|}{ D. cordata } \\
\hline CMI & $>1024$ & $>1024$ & 512 & 512 & $>1024$ & 512 & $>1024$ & $>1024$ & $>1024$ & $>1024$ & $>1024$ \\
\hline $\mathrm{CMB}$ & / & / & $>1024$ & $>1024$ & / & $>1024$ & / & I & / & / & \\
\hline $\mathrm{CMB} / \mathrm{CMI}$ & / & / & / & / & / & / & / & / & / & / & \\
\hline \multicolumn{12}{|l|}{ D. edulis } \\
\hline $\mathrm{CMI}$ & 256 & 256 & 128 & 64 & 64 & 256 & 256 & 256 & 128 & 128 & 256 \\
\hline CMB & 512 & 512 & 256 & 256 & 128 & 1024 & 1024 & 1024 & 256 & 256 & 1024 \\
\hline $\mathrm{CMB} / \mathrm{CMI}$ & 2 & 2 & 2 & 4 & 2 & 4 & 4 & 4 & 2 & 2 & 4 \\
\hline \multicolumn{12}{|l|}{ E. speciosa } \\
\hline $\mathrm{CMI}$ & $>1024$ & 256 & 512 & 64 & 256 & 256 & 512 & 256 & 512 & 256 & 512 \\
\hline CMB & / & 1024 & 1024 & 128 & 512 & 512 & 1024 & $>1024$ & $>1024$ & 1024 & $>1024$ \\
\hline $\mathrm{CMB} / \mathrm{CMI}$ & / & 4 & 2 & 2 & 2 & 2 & 2 & / & / & 4 & / \\
\hline \multicolumn{12}{|l|}{ K. crenata } \\
\hline $\mathrm{CMI}$ & 256 & 512 & 256 & 256 & 256 & 512 & $>1024$ & $>1024$ & 128 & 128 & 256 \\
\hline $\mathrm{CMB}$ & 512 & $>1024$ & 512 & 1024 & 1024 & 1024 & / & / & 256 & 256 & 512 \\
\hline $\mathrm{CMB}$ & 2 & / & 2 & 4 & 4 & 2 & / & / & 2 & 2 & 2 \\
\hline \multicolumn{12}{|c|}{ O.gratissimum } \\
\hline $\mathrm{CMl}$ & 256 & 128 & 256 & 128 & 256 & 256 & 256 & 512 & 512 & 64 & 128 \\
\hline $\mathrm{CMB}$ & 512 & 256 & 1024 & 512 & 512 & 512 & 512 & $>1024$ & 1024 & 128 & 256 \\
\hline $\mathrm{CMB} / \mathrm{CMI}$ & 2 & 2 & 4 & 4 & 2 & 2 & 2 & & 2 & 2 & 2 \\
\hline \multicolumn{12}{|l|}{ P. oleracea } \\
\hline CMI & $>1024$ & 512 & 512 & $>1024$ & $>1024$ & $>1024$ & $>1024$ & $>1024$ & $>1024$ & 512 & $>1024$ \\
\hline $\mathrm{CMB}$ & / & 1024 & 1024 & / & / & l & / & / & / & 1024 & I \\
\hline $\mathrm{CMB} / \mathrm{CMI}$ & / & 2 & 2 & / & / & / & / & / & / & 2 & / \\
\hline \multicolumn{12}{|l|}{ S. dulcis } \\
\hline $\mathrm{CMI}$ & 512 & 256 & 512 & 512 & $>1024$ & 512 & 512 & 512 & 512 & 128 & 256 \\
\hline $\mathrm{CMB}$ & $>1024$ & 512 & $>1024$ & $>1024$ & & 1024 & $>1024$ & $>1024$ & 1024 & 256 & 1024 \\
\hline $\mathrm{CMB} / \mathrm{CMl}$ & & 2 & & & & 2 & & & 2 & 2 & 4 \\
\hline \multicolumn{12}{|l|}{ S. filicaulis } \\
\hline $\mathrm{CMI}$ & 512 & 256 & 256 & 512 & 256 & 512 & $>1024$ & 256 & 512 & 128 & 256 \\
\hline $\mathrm{CMB}$ & 1024 & 1024 & 512 & $>1024$ & 512 & 1024 & / & 1024 & $>1024$ & 256 & 512 \\
\hline $\mathrm{CMB} / \mathrm{CMI}$ & 2 & 4 & 2 & / & 2 & 2 & / & 4 & & 2 & 2 \\
\hline \multicolumn{12}{|c|}{ S. veronicifolia } \\
\hline CMI & 512 & $>1024$ & $>1024$ & $>1024$ & $>1024$ & $>1024$ & $>1024$ & $>1024$ & $>1024$ & 128 & $>1024$ \\
\hline CMB & 1024 & / & I & / & I & I & / & I & / & 512 & I \\
\hline CMB/CMI & 2 & / & / & / & / & / & / & / & I & 4 & / \\
\hline
\end{tabular}


Table 3 continued

\begin{tabular}{|c|c|c|c|c|c|c|c|c|c|c|c|}
\hline & $\begin{array}{l}\text { Staph } 23 \\
\text { JN }\end{array}$ & $\begin{array}{l}\text { Staph } \\
55 \mathrm{M}\end{array}$ & $\begin{array}{l}\text { Staph } 67 \\
\text { JN }\end{array}$ & $\begin{array}{l}\text { Staph } 18 \\
\text { JL }\end{array}$ & $\begin{array}{l}\text { Staph } \\
79 \mathrm{M}\end{array}$ & $\begin{array}{l}\text { Staph } \\
58 \mathrm{M}\end{array}$ & $\begin{array}{l}\text { Staph } 22 \\
\text { JN }\end{array}$ & $\begin{array}{l}\text { Staph } \\
70 \mathrm{M}\end{array}$ & $\begin{array}{l}\text { Staph } 02 \\
\text { JN }\end{array}$ & $\begin{array}{l}\text { Staph } \\
94 \mathrm{M}\end{array}$ & $\begin{array}{l}\text { Staph } \\
75 \mathrm{~N}\end{array}$ \\
\hline \multicolumn{12}{|c|}{ Ciprofloxacine } \\
\hline $\mathrm{CMI}$ & 1,25 & 0.625 & 2.5 & 1.25 & 2.5 & 5 & 1.25 & 0.312 & 0.625 & 1.25 & 0.625 \\
\hline $\mathrm{CMB}$ & 5 & 0.625 & 2.5 & 5 & 2.5 & 5 & 5 & 1.25 & 5 & 1.25 & 1.25 \\
\hline $\mathrm{CMB} / \mathrm{CMI}$ & 4 & 1 & 4 & 1 & 1 & 4 & 4 & 8 & 8 & 1 & 2 \\
\hline
\end{tabular}

Staph: Staphylococcus aureus, / no activity

Each of the extract of D. edulis, O. gratissimum, S. dulcis, S. filicaulis, C. erecta and E. spciosa tested in the present study displayed antibacterial activity on bacterial isolates tested. This evidence emphasizes the role of ethnopharmacological data as a framework for the discovery of bioactive compounds from plants.

Antimicrobial activity of plant extracts are routinely classified on the basis of susceptibility tests that produce MICs values in the range of 500-1500 $\mu \mathrm{g} / \mathrm{ml}$ [24]. The activity is considered to be significant if MICs values are below $500 \mu \mathrm{g} / \mathrm{ml}$ and moderate when the MICs vary from 500 to $1500 \mu \mathrm{g} / \mathrm{ml}$. Based on this scale, D. edulis was found to have significant antibacterial activity on all the $11 \mathrm{~S}$. aureus isolates. O. gratissimum revealed similar activity on nine of the 11 isolates while C. erecta and S. filicaulis revealed similar results on 6 of the 11 clinical isolates. In general, $\mathrm{MBC} / \mathrm{MIC}$ ratios less than or equal to four signifies a bactericidal effect of the test substance [15]. This indicates that the bactericidal effect of the active plant extracts could be expected.

Previous studies on the antibacterial activity of the essential oil of Lippia sidoides on clinical isolates of $S$. aureus had revealed a much important activity compared to other plants (MIC $400 \mu \mathrm{l} / \mathrm{ml})$ [25]. The above plant extracts have proven much higher activities. Therefore these plants could be good candidates to overcome infectious diseases associated with $S$. aureus. These results are relevant since this microorganism is one of the most important human pathogens associated with hospital and community-acquired infections. Over the last few decades, the number and proportion of methicillin-resistant $S$. aureus infections in different countries has increased due to the rise of epidemics in humans $[2,26]$ and other animals, such as dogs, cats, cattle, pigs and exotic species [27].

Dacryodes. edulis and O. gratissimum activity are in accordance with previous work. Indeed, significant antibacterial activity of these plants on many bacterial species including $S$. aureus is well documented [10, 28-31]. Nevertheless, the real extend of this previous antibacterial results could not be compared to the present finding since the agar diffusion tests were performed.
The antibacterial activity of $S$. dulcis [32], S. filicaulis [33] and K. crenata [20] was earlier reported on Gram negative and Gram positive bacteria including $S$. aureus. Except $K$. crenata extract which revealed similar weak activity on S. aureus [15]. It was difficult to compare the limit as earlier mentioned. The present findings are therefore additional data that support the antibacterial activity of these plants as potent candidates to overcome infections associated with bacteria including $S$. aureus. To the best of our knowledge, the antibacterial activity of C. erecta and particularly on $S$. aureus is reported here for the first time.

The phytochemical screening was in accordance with reported data but slight differences were noted [15, 30, 34-36]. The phytochemical groups found in these extract could explain the antibacterial activity observed as well as the differences since the secondary metabolites of plants have many effects including antimicrobial properties [37]. Moreover, the differences could be attributed mainly to the chemical reaction method commonly used to identify the phytochemical groups of constituents. In fact, plant extracts are usually colored and this may mask specific color of some particular phytochemical group. The origin of the plant materials and the nature of the solvent for extraction are other factors that may affect the composition. Moreover, the distribution of these phytochemical groups varied from one organ to another.

\section{Conclusion}

The present finding showed that D. eduli, O. gratissimum, C. erecta and S. filicaulis possess interesting inhibitory properties against $S$. aureus species. These data are promising and could encourage further researches on phytochemical, toxicological and pharmacological aspects of these extract-products in order to support their possible rational use in antimicrobial therapy, particularly, in antiS. aureus therapy.

\section{Abbreviations}

MIC: minimal inhibitory concentrations; MBC: minimal bactericidal concentrations; DMS: dimethylsulfoxide; INT: iodonitrotetrazolium chloride. 


\section{Authors' contributions}

LFS is the field investigator; RSM is the co-field investigator and conceive the manuscript, TC design the study and supervised the work, MOK contributed in the lab work and also revised the manuscript GSSN revised the manuscript, JNN contributed in the lab work, JRK supervised the work and revised the manuscript. All authors read and approved the final manuscript.

\section{Author details}

${ }^{1}$ Laboratory of Microbiology and Antimicrobial Substances, Faculty of Science, P.O. Box 67, Dschang, Cameroon. ${ }^{2}$ Institute of Fisheries and Aquatic Sciences, University of Douala, P.O. Box 7236, Douala, Cameroon.

\section{Acknowledgements}

Authors acknowledge the National Herbarium of Yaoundé, Cameroon for plant identification.

\section{Competing interests}

The authors declared that they have no competing interests.

Received: 7 May 2015 Accepted: 2 November 2015

Published online: 24 November 2015

\section{References}

1. Doughart JH, Okafor B. Anti-microbial activity of Senna alata linn. East and Central. Afr J Pharm Sci. 2007;10:17-21.

2. Lee AS, Huttner B, Harbarth S. Control of methicillin-resistant Staphylococcus aureus. Infect Dis Clin North Am. 2011;25:155-79.

3. Naber CK. Staphylococcus aureus Bacteremia: epidemiology, pathophysiology, and management strategies. Clin Infect Dis. 2009;48:231-7.

4. Zriouil SB, Bekkali M, Zerouli K. Epidemiology of Staphylococcus aureus infections and nasal carriage at the Ibn Rochd University hopistal Center, Casablanca, Morocco. Braz J Infect Dis. 2012;16(3):279-83.

5. Akgul C, Saglikoglu G. Antibacterial activity of crude methanolic extract and its fractions of aerial parts of Anthemis tinctoria. Indian J Biochem Biophys. 2005;42:395-7.

6. Mariita RM, Ogol CKP, Oguge NO, Okemo PO. Antitubercular and phytochemical investigation of methanol extracts of medicinal plants used by the Samburu Community in Kenya. Trop J Pharm Res. 2010;9:379-85.

7. Ngoci SN, Mwendia CM, Mwaniki CG. Phytochemical and cytotoxicity testing of Indigofera lupatana Baker F. J Anim Plant Sci. 2011;11:1364-73.

8. Mothana RAA, Abdo SAA, Hasson S, Althawab FMN, Alaghbari SAZ, Lindequist U. Antimicrobial, antioxidant and cytotoxic activities and phytochemical screening of some yemeni medicinal plants. Evid Based Complement Alternat Med. 2010;6(3):36-49.

9. Ubaka MC, Ukwe VC, Okoye CT, Adibe OM. Investigation into the antiulcer activity of the aqueous leaf extract of Aspilia africana C.D. Adams. Asian J Med Sci. 2010;2(2):40-3.

10. Ajibesin KK. Dacryodes edulis (G. Don) H.J. Lam: A review on its medicinal. Phytochemical and economical medicinal plant. Res J Med Plant. 2011;5(1):32-41.

11. Sowemimo A, Maryna W, Baatjies L, Koekemoer T. Cytotoxicity evaluation of selected Nigerian plants used in traditional cancer treatment. J Med Plants Res. 2011;5(11):2442-4.

12. Julius E, Oben S, Asi E, Agbor GA, Musoro DF. Antimicrobial effects of Thai medicinal plants against acne-inducing bacteria. J Ethnopharmacol. 2006;101:330-3.

13. Okokon JE, Antia BS, Udoh AE, Akpan MM. Antianaemic and antimicrobial activity of Eremomastax speciosa. J Pharmacol Toxicol. 2007;2:196-9.

14. Dimo T, Nguelefack TB, Fotio AL, Emmanuel A, Asongalem PKT. Antiinflammatory activity of leaf extracts of Kalanchoe crenata Andr. Indian J Pharmacol. 2004;38:115-9.

15. Yimta F, Mouokeu RS, Nguimatsia F, Njateng GSS, Tamokou JDD, Kuiate JR: Antibacterial activity of methanol extracts and fractions from Kalanchoe crenata, Terminalia avicennioides and Sarcocephallus latifolius. Pharmacologia 2014, 199-204.

16. Apinya P, Udomsilp J, Khang-Khun P, Thobunluepop P: Evaluation of potential antimicrobial activity of some medicinal plants against common food-borne pathogenic microoganisms. Asian Journal of Food and Agro-Industry, 2009, 2-9.

17. Mbata TI, Lu Debiao Saikia A. Antibacterial activity of the crude extract of Chinese green tea. Int J Microbiol. 2009;2(2):1-6.

18. Bakkiyaraj S, Pandiyara S, Avadi V. Evaluation of potential antimicrobial activity of some medicinal plants against common food-borne pathogenic microoganism. Int J Pharma Bio Sci. 2011;2(2):484-91.

19. Saikia R, Choudhur MD, Talukdar AD, Pankaj C. Antidiabetic activity of ethno medicinal plant Scoparia dulcis L. (Family: Scrophulariaceae): a review. Assam Univ J Sci Technol. 2011;7(1):173-80.

20. Franzotti EM, Santos CV, Rodrigues HM, Mourão RH, Andrade M, Antoniolli A. Anti-inflammatory, analgesic activity and acute toxicity of Sida cordifolia L. (Malva-branca). J Ethnopharmacol. 2000;72(1-2):273-7.

21. Harbone JB. Phytochemical methods. New York: Chapman \& Hall; 1973. p. $1-150$.

22. Mekonnen A, Mahinda P, Moses NK. Isolation and identification of Staphyloccucu species from Ethiopian cottage Cheese (Ayib) in Debre zeit. Ethiop Vet. Res. 2011;4(1):13-7.

23. Kuete V, Ngameni B, Simo CCF, Tankeu RK, Ngadjui BT, Meyer JJ, Lall N, Kuiate JR. Antimicrobial activity of the crude extracts and compounds from Ficus chlamydocarpa and Ficus cordata (Moraceae). J Ethnopharmacol. 2008;120:17-24

24. Aligiannis N, Kalpotzakis E, Mitaku S, Chinou IB. Composition and antimicrobial activity of the essential oil of two Origanum species. J Agric Food Chem. 2001;40:4168-70.

25. Oliveira PF, Edeltrudes OL, José PSJ, Evandro LS, Bernadete HCS, Humberto MB. Effectiveness of Lippia sidoides Cham. (Verbenaceae) essential oil in inhibiting the growth of Staphylococcus aureus strains isolated from clinical material. Braz J Pharmacogn. 2006;16(4):510-6.

26. Rodríguez-Noriega E, Seas C, Guzmán-Blanco M, Mejía C, Alvarez C, Bavestrello L, et al. Evolution of methicillin-resistant Staphylococcus aureus clones in Latin America. Int J Infect Dis. 2010;14:560-6.

27. Smith TC, Pearson N. The emergence of Staphylococcus aureus ST398. Vector Borne Zoonotic Dis. 2011;11:327-39.

28. Idu M, Erhabor JO, Towuru GE. Antimicrobial effects of the chloroform and ethanolic leaf extracts of Dacryodes Edulis (G. Don) H.J. Lam, Garcinia Kola Heckel and Chrysophyllum Albidum G. done on some test isolates. Med Sci. 2013;1(3):63-6.

29. Nwokonkwo DC. The phytochemical study and antibacterial activities of the seed extract of Dacryodes Edulis (African Native Pear). Am J Sci Ind Res. 2014;5(1):7-12.

30. Mann A. Phytochemical constituents and antimicrobial and grain protectant activities of clove basil (Ocimum gratissimum L.) grown in Nigeria. International. J Plant Res. 2012;2(1):51-8.

31. Akinjogunla OJ, Ekoi OH, Odeyemi AT. Phytochemical screening and in vitro antibacterial assessment of aqueous leaf extracts of Vernonia amygdalina (Asteraceae) and Ocimum gratissimum (Lamiaceae) on moxifloxacin resistant Escherichia coli isolated from clinical and environmental samples. Nat Sci. 2011;9(7):42-52.

32. Latha MKM, Ramkumar L, Pari PNPN, Damodaran V, Rajeshkannan TS. Phytochemical and antimicrobial study of an antidiabetic plant: scoparia dulcis. J Med Food. 2006;9(3):391-4.

33. Akoachere TKJF, Suylika Y, Mbah JA, Ayimele GA, Assob NCJ, Fodouop CPS, et al. In vitro Antimicrobial cctivity of agents from Spilanthes filicaulis and Laportea ovalifolia against some drug resistant bacteria. BJPR. 2015;6(2):76-87.

34. Nweze El, Eze EE. Justification for the use of Ocimum gratissimum L in herbal medicine and its interaction with disc antibiotics. BMC Complement Altern Med. 2009;9:37.

35. Uma G, Najila BA, Sathica TJ, Josephine BBU. Phytochemical screening and antibacterial activity of Scoparia dulcis extracts. Asian J Pharm Clin Res. 2014;7(3):130-3.

36. Ndam LM, Mih AM, Fongod AGN, Tening AS, Tonjock RK, Enang JE, et al. Phytochemical screening of the bioactive compounds in twenty (20) Cameroonian medicinal plants. Int J Curr Microbiol App Sci. 2014;3(12):768-78.

37. Cowan MM. Plant products as antimicrobial agents. Clin Microbiol Rev. 1999;12:564-82. 